\title{
A Study on the Influence of Language Learning Strategy Training on Learners' Beliefs
}

\author{
$\mathrm{Na}$ Yang \\ Foreign Language School, Southwest Petroleum University, Xindu, Chengdu, Sichuan, China \\ Li Gao \\ Foreign Language School, Southwest Petroleum University, Xindu, Chengdu, Sichuan, China \\ Jie Zeng \\ Foreign Language School, Southwest Petroleum University, Xindu, Chengdu, Sichuan, China
}

\begin{abstract}
As one of the learner factors, most of the reported researches concerning learners' beliefs mainly deal with the correlation between learners' beliefs and other learner factors, and mostly belong to crosssectional study. By contrast, learners' beliefs are investigated longitudinally in this study---respectively before, after and half a year after a language learning strategy training: TCLTSP model. The influence of the training on learners' beliefs is analyzed based on the changes of learners' beliefs.
\end{abstract}

Index Terms - learners' beliefs, learning strategy training, TCLTSP model

\section{INTRODUCTION}

From 1970s, the research emphasis of applied linguistics has been regularly transferred from How to teach to How to learn. Much attention has been given to studies on learner factors, among which learners' beliefs and learning strategy become typical hot issues, many related studies have been carried out and some findings are achieved (Ellis 1994 (cited in Jiao, 2006); Yang 1999; Wen 2001). Those studies indicate that learners' beliefs and learning strategy are two essential factors for foreign language learning, which exert great influence on learning behavior and learning outcome; learners' beliefs have strong influence on learning strategy; Yang (1999) suggested through study that the relationship between learners' beliefs and learning strategy should be cyclical rather than uni-directional. Therefore, this study intends to analyze first-year English majors' beliefs in Southwest Petroleum University in China, aiming at proving the cyclical relationship between learners' beliefs and learning strategy by exploring the possible influence that TCLTSP strategy training exerted on learners' beliefs.

\section{REVIEW OF RESEARCHES ON THE RELATIONSHIP BETWEEN LEARNERS’ BELIEFS AND LEARNING STRATEGy}

To date, many researches concerning learner factors involve the survey of both leaning strategy and learners' beliefs, according to the findings and results that have been reported, these two important learner factors turn out to be closely associated. Horwitz (1988) uses the questionnaire developed by herself --- Beliefs about Language Learning Inventory to sort and describe the beliefs of the first-year students enrolled in University of Texas. She also admits the existence of the impact of learners' beliefs on learning strategies. Ellis (1994, cited in Jiao,2006) puts forward a framework for investigating individual learner differences, which shows that beliefs about language learning, learning strategies and language learning outcomes are interrelated. Wen (1995) puts forward a framework which shows that learners' beliefs, learning strategies and learning outcome are interrelated, then she claims that learners' beliefs have direct effect on their strategies, thus on their learning outcome. Yang (1999) conducts a study aiming to provide a better understanding of the relationship between learners' beliefs and learning strategy use. The results imply cyclical relationship between learners' beliefs and strategy use.

\section{LANGUAGE LEARNING STRATEGy TRAINING--- TCLTSP MODEL}

TCLTSP model is designed based on the previously reported strategy training models by Jones et al. (1987); O'Malley \& Chamot (1990); Oxford (1990) (cited in Gao, 2017). The model is developed through the practices of language learning strategy training for Chinese language majors who learn English as a foreign language. The detailed information of the training are listed in the following tables and figures: 
TABLE 1:

COMPONENTS OF TCLTSP MODEL

\begin{tabular}{|l|l|}
\hline TCLTSP & The meaning of each component \\
\hline T & Tasks experiencing \\
\hline C & Contributions of teacher/tutors/group members \\
\hline L & Learners' self-understanding \\
\hline T & understanding of Target \\
\hline S & understanding learning Strategies \\
\hline P & taking conscious control of learning Process \\
\hline
\end{tabular}

TABLE 2:

THE CURRICULUM OF TCLTSP MODEL STRATEGY TRAINING

\begin{tabular}{|l|l|}
\hline Unit1. Learner Preference & \multirow{2}{*}{ Meta cognitive strategy } \\
\hline Unit2. Goals, Motivation and Perseverance & \multirow{2}{*}{ Cognitive strategy } \\
\hline Unit10. Reflections & \\
\hline Unit3. Memory and vocabulary & \\
\hline Unit4. Reading & \multirow{2}{*}{ Social strategy } \\
\hline Unit5. Listening & \\
\hline Unit6. Speaking & \\
\hline Unit7. Writing strategies & \\
\hline Unit8. Positioning in a grouping & \\
\hline Unit9. Cross-Cultural Communication &
\end{tabular}

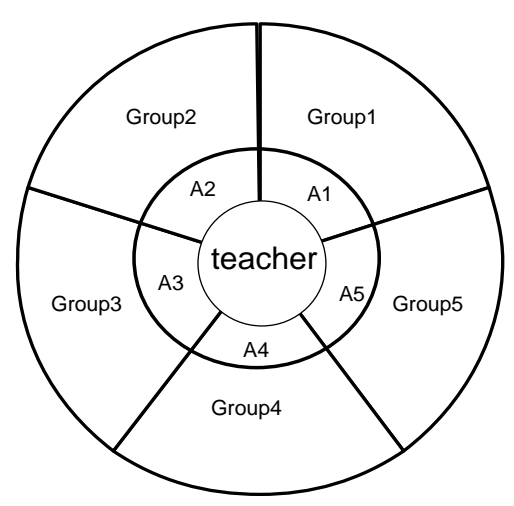

Figure 1: Teaching form of TCLTSP

Teacher stands for the main teacher A stands for teaching assistant/tutor

In addition to having a main teacher delivering each lecture, students were divided into five groups with a tutor respectively. All the tutors are graduate students of English majors and are responsible for organizing the discussion activities, keeping record the performance of each student in the group. Team teaching echoes the purposes of TCLTSP training mode, which aims at helping students understand themselves better, understand learning tasks better, understand learning strategies better through discussions and reflections so that taking conscious control of learning process can be gradually achieved.

\section{THE STUDY ON LEARNERS’ BELIEFS BEFORE AND AFTER TCLTSP STRATEGY TRAINING}

\section{A. The Quantitative Study}

\section{Research Questions}

(1) What were the beliefs held by the subjects before the language strategy training?

(2) What are the differences of learners' beliefs among pre test, post test and delayed post test?

\section{Research Subjects}

All the subjects are first year English majors in Southwest Petroleum University because freshmen bring preconceptions about English language learning based on the previous learning experience, some of which probably contain misconceptions, therefore, it's necessary to examine their initial beliefs as freshmen and conduct language training to reshape or correct learners' beliefs. 
TABLE 3

INFORMATION OF SUBJECTS: SEX RATIO

\begin{tabular}{|l|l|l|l|l|l|}
\hline \multicolumn{2}{|c|}{} & Frequency & Percent & Valid Percent & Cumulative Percent \\
\hline \multirow{3}{*}{ Valid } & male & 33 & 28.4 & 28.4 & 28.4 \\
\cline { 2 - 6 } & female & 83 & 71.6 & 71.6 & 100 \\
\cline { 2 - 6 } & Total & 116 & 100 & 100 & \\
\hline
\end{tabular}

\section{Research Instruments-Questionnaire}

The questionnaire in the present study is adapted from the widely used questionnaire Beliefs about Language Learning Inventory (BALLI) developed by Horwitz (1987).

TABLE 4:

STRUCTURE OF THE QUESTIONNAIRE

\begin{tabular}{|l|l|l|}
\hline & Contents & Number of items \\
\hline Part I: Title & Learners' Beliefs on English Language Learning & \\
\hline Part II: Personal Information & Student number, sex, class & 3 \\
\hline \multirow{2}{*}{ Part III: Introduction } & $\begin{array}{l}\text { Brief introduction of the purpose of the survey and the } \\
\text { way to respond }\end{array}$ & \\
\hline \multirow{4}{*}{$\begin{array}{l}\text { Part IV: } \\
\text { Learners' Beliefs on English }\end{array}$} & 1.About the difficulty of language learning & 6 \\
\cline { 2 - 3 } & 2.About foreign language aptitude & 6 \\
\cline { 2 - 3 } & 3.About the nature of language learning & 6 \\
\cline { 2 - 3 } & 4.About learning and communication strategies & 8 \\
\cline { 2 - 3 } & 5.About motivations and expectations & 4 \\
\cline { 2 - 3 } & 6.About classroom teaching for English language learning & 2 \\
\hline
\end{tabular}

TABLE 5

Reliability Statistics

\begin{tabular}{|r|r|}
\hline $\begin{array}{c}\text { Cronbach's } \\
\text { Alpha }\end{array}$ & $\mathrm{N}$ of Items \\
\hline .763 & 32 \\
\hline
\end{tabular}

Data Collection and Analysis

To analyze the data, Statistical Package of Social Science SPSS13.0 was applied

B. The Qualitative Study

\section{Research Questions}

How does the training affect learners' beliefs corresponding with what students report?

In order to answer the above question, four more detailed questions are designed.

1. What is your biggest problem in English language learning? Why?

2. Are you getting used to make plan for language learning? What are your short-term and long-term goals?

3. What are the qualities are you looking for a good language learner?

4. How does the language strategy training course influence your language learning? What are your suggestions for the training?

\section{Research Subjects}

Among the 116 subjects who had taken part in the questionnaire survey, nine of them were selected and agreed to participate the in-depth study. According to their scores for college admission, among the nine participants for qualitative study, three of them are chosen from the highest scores, three are from mid-level scores and three are from the lowest scores.

\section{Data collection and analysis}

The entire interview was recorded and transcribed into written materials and was analyzed by the author. Details that closely related to the raised questions were selected for in-depth analysis while other irrelevant data were put aside.

\section{Results and Discussion}

\section{Descriptive Analysis of Learner's Beliefs on English Learning}

The statistical measure of descriptive analysis was employed to analyze the quantitative data, items such as mean sores, frequency and std. deviation are to be presented and discussed

Beliefs about the Difficulty of Language Learning 
TABLE 6

MEAN SCORES OF THE DIFFICULTY OF LANGUAGE LEARNING

\begin{tabular}{|l|l|l|l|l|l|l|}
\hline & $\begin{array}{l}\text { Some } \\
\text { languages are } \\
\text { easier to learn } \\
\text { than other } \\
\text { languages. }\end{array}$ & $\begin{array}{l}\text { The degree of the } \\
\text { difficulty of English } \\
\text { learning: very } \\
\text { difficult; difficult; } \\
\text { medium difficulty; } \\
\text { easy; very easy. }\end{array}$ & $\begin{array}{l}\text { I have the } \\
\text { confidence } \\
\text { that I will } \\
\text { speak English } \\
\text { fluently one } \\
\text { day. }\end{array}$ & $\begin{array}{l}\text { How long will it } \\
\text { take one to learn } \\
\text { English well if he } \\
\text { spends one hour on } \\
\text { English learning } \\
\text { each day? }\end{array}$ & $\begin{array}{l}\text { It is easier to } \\
\text { speak English } \\
\text { well than to } \\
\text { understand } \\
\text { English clearly. }\end{array}$ & $\begin{array}{l}\text { Reading and } \\
\text { listening are } \\
\text { easier than } \\
\text { speaking and } \\
\text { writing. }\end{array}$ \\
\hline Items & SMEAN(D1) & $\begin{array}{l}\text { SMEAN } \\
\text { (D2) }\end{array}$ & SMEAN(D3) & $\begin{array}{l}\text { SMEAN } \\
\text { (D4) }\end{array}$ & $\begin{array}{l}\text { SMEAN } \\
\text { (D5) }\end{array}$ & $\begin{array}{l}\text { SMEAN } \\
\text { (D6) }\end{array}$ \\
\hline N Valid & 116 & 116 & 116 & 116 & 116 & 116 \\
\hline$\quad$ Missing & 0 & 0 & 0 & 0 & 0 & 2.7931 \\
\hline Mean & 3.9483 & 3.2222 & 4.487 & 3.8796 & 2 & 3.0531 \\
\hline Mode & 4 & 3 & 5 & 5 & 1.24773 & 4 \\
\hline Std. Deviation & 1.02867 & 0.74988 & 0.76175 & 1.15508 & 1.16351 \\
\hline
\end{tabular}

TABLE 7

FREQUENCY OF THE DIFFICULTY OF LANGUAGE LEARNING

\begin{tabular}{|l|l|l|l|l|l|l|l|l|l|l|l|l|}
\hline & D1 & D2 & D3 & D4 & D5 & D6 \\
\cline { 2 - 15 } & Fre. & Per. & Fre. & Per. & Fre. & Per. & Fre. & Per. & Fre. & Per. & Fer. & Per. \\
\hline 1 & 3 & 2.6 & 2 & 1.7 & & & 3 & 2.6 & 16 & 13.8 & 11 & 9.5 \\
\hline 2 & 10 & 8.6 & 12 & 10.3 & 4 & 3.4 & 15 & 12.9 & 43 & 37.1 & 29 & 25 \\
\hline 3 & 16 & 13.8 & 59 & 50.9 & 7 & 6 & 21 & 18.1 & 19 & 16.4 & 32 & 27.6 \\
\hline 4 & 48 & 41.4 & 38 & 32.8 & 34 & 37.4 & 30 & 25.9 & 25 & 21.6 & 31 & 26.7 \\
\hline 5 & 39 & 33.6 & 5 & 4.3 & 71 & 61.2 & 47 & 40.5 & 13 & 11.2 & 13 & 11.2 \\
\hline Total & 116 & 100 & 116 & 100 & 116 & 100 & 116 & 100 & 116 & 100 & 116 & 100 \\
\hline
\end{tabular}

According to table 6, item D1, D3 and D4 respectively reached 3.9483, 4.4870 and 3.8796. The results indicate that the mean scores of these three items are at high level (3.5-5.0).

In table 7 , only $1.7 \%$ of the subjects find English a very difficult language, which may due to their identity of English majors with better foundation of English language. As for the confidence of mastering spoken English, according to the data in table 7, none of the subjects lacks this confidence, which presents a very optimistic statement of learning English well from English majors. Subjects who hold the idea that no one can learn English well by spending only one hour per day take the largest proportion (40.5\%), and another $25.9 \%$ think that it might take five to ten years to learn English well, which indicate that most language major students understand clearly that language learning requires both time and efforts.

As for the difficulty of specific language skills, table 7 shows that more than half of the subjects (50.9\%) show their disagreement to the statement of speaking is easier than listening. As for the difficulty of reading and writing versus listening and speaking, subjects who hold neutral attitude take a comparatively higher proportion (27.6\%), while the proportion of subjects hold either agreement or disagreement to item six (Reading and listening are easier than speaking and writing.) does not differ too much (25\% vs 26.7\%). The result suggests that as English majors, the strength and interest in English learning of the subjects vary from person to person.

\section{Beliefs about the Aptitude of Language Learning}

TABLE 8

MEAN SCORES OF THE ABILITY OF LANGUAGE LEARNING

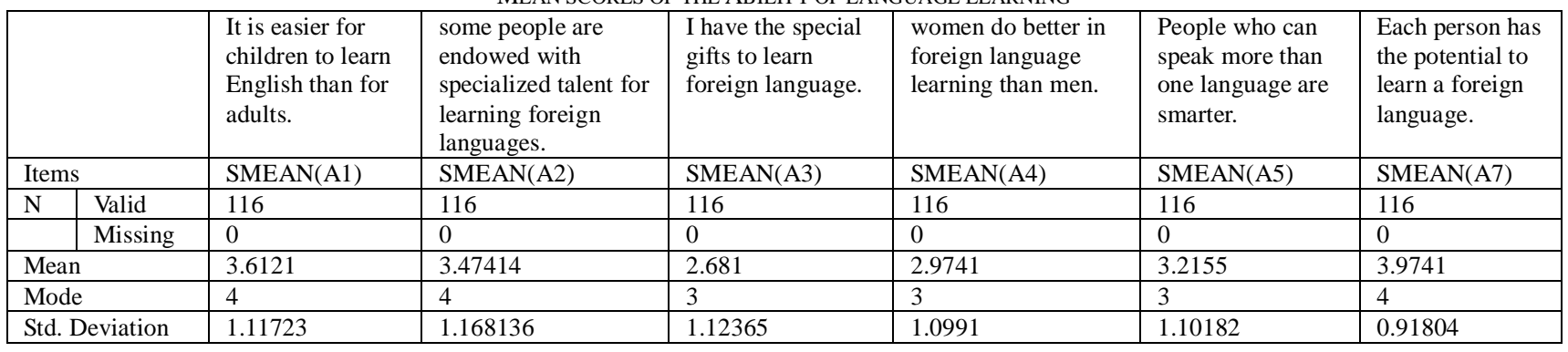

TABLE 9

FREQUENCY OF THE ABILITY OF LANGUAGE LEARNING

\begin{tabular}{|c|c|c|c|c|c|c|c|c|c|c|c|c|}
\hline & \multicolumn{2}{|l|}{ A1 } & \multicolumn{2}{|l|}{ A2 } & \multicolumn{2}{|l|}{ A3 } & \multicolumn{2}{|l|}{ A4 } & \multicolumn{2}{|l|}{ A5 } & \multicolumn{2}{|l|}{ A7 } \\
\hline & Fre. & Per. & Fre. & Per. & Fre. & Per. & Fre. & Per. & Fre. & Per. & Fer. & Per. \\
\hline 1 & 7 & 6 & 9 & 7.8 & 22 & 19 & 12 & 10.3 & 6 & 5.2 & & \\
\hline 2 & 12 & 10.3 & 5 & 12.9 & 26 & 22.4 & 27 & 23.3 & 25 & 21.6 & 9 & 7.8 \\
\hline 3 & 25 & 21.6 & 26 & 22.4 & 40 & 34.5 & 37 & 31.9 & 40 & 34.5 & 23 & 19.8 \\
\hline 4 & 47 & 40.5 & 44 & 37.9 & 23 & 19.8 & 32 & 27.6 & 28 & 24.1 & 46 & 39.7 \\
\hline 5 & 25 & 21.6 & 22 & 19 & 5 & 4.3 & 8 & 6.9 & 17 & 14.7 & 38 & 32.8 \\
\hline Total & 116 & 100 & 16 & 100 & 116 & 100 & 116 & 100 & 116 & 100 & 116 & 100 \\
\hline
\end{tabular}


According to table 8 and table 9, 62.1\% of the subjects agree that learning English is easier for children than for adults, only $16.3 \%$ show their disagreement. More than half of the subjects $(56.9 \%)$ approve that some people are endowed with specialized talent for learning foreign languages, which indicates the innate idea of those subjects and they may partly contribute language learning success or failure to individual talent. As for personal talent for foreign language learning, only $24.1 \%$ acknowledge their specialized talents, $34.5 \%$ show neutral attitude, while subjects who deny that they own specialized talents for foreign language leaning take the largest proportion with $41.4 \%$, the truth that most of the subjects $(75.9 \%)$ are not sure about of their talents for foreign language learning is likely to evoke their efforts and diligence to learn English.

Data of responses to the statement that women do better in foreign language learning than men turn out to be average with $33.6 \%$ of disagreement, $31.9 \%$ of neutral attitude and $34.5 \%$ of agreement. This result shows no bias from the subjects on gender differences for foreign language learning. It may due to the truth that most of the subjects are female, as data displayed in table 3. As for individual potential for learning a foreign language, vast majority of the subjects $(72.5 \%)$ admit each person has the potential to learn a foreign language with only $7.8 \%$ of disagreement. This reveals their confidence in studying their major---English well.

Beliefs about the Nature of Language Learning

TABLE 10

MEAN SCORES OF THE NATURE OF LANGUAGE LEARNING

\begin{tabular}{|c|c|c|c|c|c|c|c|}
\hline & & $\begin{array}{l}\text { It's necessary to } \\
\text { know foreign } \\
\text { cultures to facilitate } \\
\text { foreign language } \\
\text { learning }\end{array}$ & $\begin{array}{l}\text { Learning } \\
\text { English in } \\
\text { English speaking } \\
\text { countries would } \\
\text { be better. }\end{array}$ & $\begin{array}{l}\text { The primary task } \\
\text { of English } \\
\text { learning is } \\
\text { vocabulary. }\end{array}$ & $\begin{array}{l}\text { The primary } \\
\text { task of } \\
\text { English } \\
\text { learning is } \\
\text { grammar. }\end{array}$ & $\begin{array}{l}\text { Learning a } \\
\text { foreign } \\
\text { language is } \\
\text { quite different } \\
\text { from learning } \\
\text { other subjects. }\end{array}$ & $\begin{array}{l}\text { Chinese-English } \\
\text { translation is the } \\
\text { is the most } \\
\text { important issue in } \\
\text { English learning. }\end{array}$ \\
\hline \multicolumn{2}{|c|}{ Items } & $\begin{array}{l}\text { SMEAN } \\
\text { (N1) }\end{array}$ & SMEAN(N2) & $\begin{array}{l}\text { SMEAN } \\
\text { (N3) }\end{array}$ & SMEAN(N4) & $\begin{array}{l}\text { SMEAN } \\
\text { (N5) }\end{array}$ & $\begin{array}{l}\text { SMEAN } \\
\text { (N6) }\end{array}$ \\
\hline \multirow[t]{2}{*}{$\mathrm{N}$} & Valid & 116 & 116 & 116 & 116 & 116 & 116 \\
\hline & Missing & 0 & 0 & 0 & 0 & 0 & 0 \\
\hline \multicolumn{2}{|c|}{ Mean } & 4.6379 & 4.0517 & 3.5 & 2.7414 & 3.7586 & 2.2328 \\
\hline \multicolumn{2}{|c|}{ Mode } & 5 & $4.00(\mathrm{a})$ & 4 & 3 & 4 & 2 \\
\hline \multicolumn{2}{|c|}{ Std. Deviation } & 0.56563 & 0.94955 & 0.95553 & 0.90526 & 0.99232 & 0.9812 \\
\hline
\end{tabular}

TABLE 11

FREQUENCY OF THE NATURE OF LANGUAGE LEARNING

\begin{tabular}{|c|c|c|c|c|c|c|c|c|c|c|c|c|}
\hline & \multicolumn{2}{|l|}{ N1 } & \multicolumn{2}{|l|}{ N2 } & \multicolumn{2}{|l|}{ N3 } & \multicolumn{2}{|l|}{ N4 } & \multicolumn{2}{|l|}{ N5 } & \multicolumn{2}{|l|}{ N6 } \\
\hline & Fre. & Per. & Fre. & Pe. & Fre. & Per. & Fre. & Per. & Fre. & Per. & Fer. & Per. \\
\hline 1 & & & 1 & 0.9 & 1 & 0.9 & 10 & 8.6 & 2 & 1.7 & 27 & 23.3 \\
\hline 2 & 1 & 0.9 & 8 & 6.9 & 18 & 15.5 & 34 & 29.3 & 12 & 10.3 & 50 & 43.1 \\
\hline 3 & 2 & 1.7 & 19 & 16.4 & 36 & 31 & 50 & 43.1 & 26 & 22.4 & 27 & 23.3 \\
\hline 4 & 35 & 30.2 & 44 & 37.9 & 44 & 37.9 & 20 & 17.2 & 48 & 41.4 & 9 & 7.8 \\
\hline 5 & 78 & 67.2 & 44 & 37.9 & 17 & 14.7 & 2 & 1.7 & 28 & 24.1 & 3 & 2.6 \\
\hline Total & 116 & 100 & 116 & 100 & 116 & 100 & 116 & 100 & 116 & 100 & 116 & 100 \\
\hline
\end{tabular}

According to the data in table10 and table 11 , almost all the subjects $(97.4 \%)$ agree that it's necessary to know foreign cultures to facilitate foreign language learning, which represents a highly approved opinion of the necessity and importance of learning foreign cultures from English majors. Similar to the case of item one, $75.8 \%$ of the subjects think that learning English in English speaking countries would be better, which indicates the importance of language environment in learners' beliefs.

As for the importance of vocabulary learning, more than half of the subjects $(52.6 \%)$ consider it the primary task for English learning, which indicates that majority of the subjects may exert more efforts in vocabulary learning. On the contrary, only $18.9 \%$ of the subjects think grammar learning is primary in English study, while $37.9 \%$ deny the priority of grammar learning, and $43.1 \%$ are not sure about this statement. By contrast, the importance of vocabulary outweighs that of grammar for most of the subjects, which will directly affect their distribution of time in working with the two parts. Similar to case of learning grammar, only $10.4 \%$ of the subjects regard Chinese-English translation as the most important issue in English learning, which suggests their anxiety of the negative influence of Chinese on English learning.

When the subjects are asked whether English learning differs learning other subjects, only $12 \%$ disagree with this statement. This proves that as English majors, most of them may have rough ideas about the features of English learning and they may probably take related factors into consideration while selecting learning approaches and strategies.

Beliefs about Language Learning and Communication Strategies 
TABLE 12

MEAN SCORES OF LEARNING AND COMMUNICATION STRATEGIES

\begin{tabular}{|c|c|c|c|c|c|}
\hline & & $\begin{array}{l}\text { It is important to } \\
\text { practice and repeat } \\
\text { a lot so as to } \\
\text { facilitate English } \\
\text { learning. }\end{array}$ & $\begin{array}{l}\text { Using tapes and } \\
\text { videos to practice } \\
\text { spoken English is } \\
\text { important and } \\
\text { necessary. }\end{array}$ & $\begin{array}{l}\text { An excellent } \\
\text { pronunciation" plays } \\
\text { an important role in } \\
\text { spoken English. }\end{array}$ & $\begin{array}{l}\text { Do not express ideas } \\
\text { in English before } \\
\text { you can speak it } \\
\text { correctly }\end{array}$ \\
\hline \multicolumn{2}{|c|}{ Items } & SMEAN(S1) & SMEAN(S2) & SMEAN(S3) & SMEAN(S4) \\
\hline \multirow[t]{2}{*}{$\mathrm{N}$} & Valid & 116 & 116 & 116 & 116 \\
\hline & Missing & 0 & 0 & 0 & 0 \\
\hline \multicolumn{2}{|c|}{ Mean } & 3.9569 & 4.4052 & 4.6207 & 2.0086 \\
\hline \multicolumn{2}{|c|}{ Mode } & 4 & 5 & 5 & 1 \\
\hline \multicolumn{2}{|c|}{ Std. Deviation } & 0.99032 & 0.63216 & 0.6277 & 4.64289 \\
\hline
\end{tabular}

\begin{tabular}{|c|c|c|c|c|c|}
\hline & & $\begin{array}{l}\text { I am willing to } \\
\text { practice spoken } \\
\text { English with } \\
\text { native speakers. }\end{array}$ & $\begin{array}{l}\text { Guessing is } \\
\text { acceptable } \\
\text { when } \\
\text { encounter } \\
\text { new words }\end{array}$ & $\begin{array}{l}\text { I feel shy when I } \\
\text { speak with others in } \\
\text { English. }\end{array}$ & $\begin{array}{l}\text { It would be difficult for } \\
\text { beginners to speak English } \\
\text { correctly later if they were } \\
\text { allowed to make mistakes in } \\
\text { initial stage of learning English }\end{array}$ \\
\hline \multicolumn{2}{|l|}{ Items } & SMEAN(S5) & SMEAN(S6) & SMEAN(S7) & SMEAN(S8) \\
\hline \multirow[t]{2}{*}{$\mathrm{N}$} & Valid & 116 & 116 & 116 & 116 \\
\hline & Missing & 0 & 0 & 0 & 0 \\
\hline Mean & & 1.8621 & 4.3017 & 2.7368 & 3.6207 \\
\hline Model & & 1 & 4 & 2 & 4 \\
\hline Std. Deviation & & 1.08665 & 0.70056 & 1.11941 & 1.10851 \\
\hline
\end{tabular}

TABLE 13

FREQUENCY OF LEARNING AND COMMUNICATION STRATEGIES

\begin{tabular}{|c|c|c|c|c|c|c|c|c|}
\hline & \multicolumn{2}{|l|}{ S1 } & \multicolumn{2}{|l|}{ S2 } & \multicolumn{2}{|l|}{ S3 } & \multicolumn{2}{|l|}{ S4 } \\
\hline & Fre. & Per. & Fre. & Per. & Fre. & Per. & Fre. & Per. \\
\hline 1 & 4 & 3.4 & & & & & 59 & 50.9 \\
\hline 2 & 5 & 4.3 & & & & & 48 & 41.4 \\
\hline 3 & 20 & 17.2 & 9 & 7.8 & 9 & 7.8 & 6 & 5.2 \\
\hline 4 & 50 & 43.1 & 51 & 44.0 & 26 & 22.4 & 1 & 0.9 \\
\hline 5 & 37 & 31.9 & 56 & 48.3 & 81 & 69.8 & 2 & 1.7 \\
\hline \multirow[t]{3}{*}{ Total } & 116 & 100 & 116 & 100 & 116 & 100 & 116 & 100 \\
\hline & \multicolumn{2}{|l|}{ S5 } & \multicolumn{2}{|l|}{ S6 } & \multicolumn{2}{|l|}{ S7 } & \multicolumn{2}{|l|}{ S8 } \\
\hline & Fre. & Per. & Fre. & Per. & Fre. & Per. & Fre. & Per. \\
\hline 1 & 3 & 2.6 & 1 & 0.9 & 16 & 13.8 & 57 & 49.1 \\
\hline 2 & 18 & 15.5 & 1 & 0.9 & 37 & 31.9 & 35 & 30.2 \\
\hline 3 & 29 & 25.0 & 7 & 6.0 & 30 & 25.8 & 10 & 8.6 \\
\hline 4 & 36 & 31.0 & 60 & 51.7 & 27 & 23.3 & 11 & 9.5 \\
\hline 5 & 30 & 25.9 & 47 & 40.5 & 6 & 5.2 & 3 & 2.6 \\
\hline Total & 116 & 100 & 116 & 100 & 116 & 100 & 116 & 100 \\
\hline
\end{tabular}

As for learning strategy, $75 \%$ of the subjects show approval of learning by practicing and repeating. As for the tools, almost all the subjects $(92.3 \%)$ prefer to use tapes and videos for spoken English learning. In terms of handling new words, 92.2\% of the subjects think "guessing" is acceptable, which is a strategic way for their future reading comprehension.

When it comes to communicative strategy, none of the subjects deny that "an excellent pronunciation" plays an important role in spoken English, which suggests that being English majors, they pay special attention to pronunciation and must exert extra efforts on this area. The data obtained from item four (Do not express ideas in English before you can speak it correctly") and eight (it would be difficult for beginners to speak English correctly later if they were allowed to make mistakes in initial stage of learning English) reveals that English majors are tolerant towards making mistakes in spoken English with only $1.7 \%$ and $2.6 \%$ respectively hold that making mistakes is harmful. More than half of the subjects (66/116) show their preference to speak with people from English speaking countries, which form sharp contrast with the research result from non-English majors in the authors' university (Jiao, 2006). Therefore, it proves that English majors expect more exposures to authentic language condition, which may explain the result that subjects do not feel shy (45.7\%) overweighs those who feel shy (28.5\%)when speaking with others in English.

Beliefs about Motivations and Expectations 
TABLE 14

MEAN SCORES OF MOTIVATIONS AND EXPECTATIONS

\begin{tabular}{|c|c|c|c|c|c|}
\hline & & $\begin{array}{l}\text { Better spoken English } \\
\text { skill accompany with } \\
\text { more chances to use } \\
\text { English. }\end{array}$ & $\begin{array}{l}\text { It will be more } \\
\text { possible for me to } \\
\text { get good job if I am } \\
\text { good at English. }\end{array}$ & $\begin{array}{l}\text { Chinese people } \\
\text { thought it is } \\
\text { important to speak } \\
\text { English well. }\end{array}$ & $\begin{array}{l}\text { I learn English with } \\
\text { purpose of knowing } \\
\text { the native speakers } \\
\text { better. }\end{array}$ \\
\hline \multicolumn{2}{|c|}{ Items } & SMEAN(M1) & SMEAN(M2) & SMEAN(M3) & SMEAN(M4) \\
\hline \multirow[t]{2}{*}{$\mathrm{N}$} & Valid & 116 & 116 & 116 & 116 \\
\hline & Missing & 0 & 0 & 0 & 0 \\
\hline \multicolumn{2}{|c|}{ Mean } & 4.4828 & 4.3103 & 4.0345 & 2.4828 \\
\hline \multicolumn{2}{|c|}{ Mode } & 5 & 5 & 4 & 3 \\
\hline \multicolumn{2}{|c|}{ Std. Deviation } & 0.70381 & 0.87887 & 0.87408 & 0.97341 \\
\hline
\end{tabular}

TABLE 15

FREQUENCY OF MOTIVATIONS AND EXPECTATIONS

\begin{tabular}{|l|l|l|l|l|l|l|l|l|}
\hline & M1 & \multicolumn{1}{|c}{} & M2 & M3 & M4 & \\
\cline { 2 - 9 } & Fre. & Per. & Fre. & Per. & Fre. & Per. & Fre. & Per. \\
\hline 1 & & & 2 & 1.7 & 2 & 1.7 & 19 & 16.4 \\
\hline 2 & 1 & 9 & 1 & 0.9 & 3 & 2.6 & 39 & 33.6 \\
\hline 3 & 11 & 9.5 & 17 & 14.7 & 21 & 18.1 & 45 & 38.8 \\
\hline 4 & 35 & 30.2 & 35 & 30.2 & 53 & 45.7 & 9 & 7.8 \\
\hline 5 & 69 & 59.5 & 61 & 52.6 & 37 & 31.9 & 4 & 3.4 \\
\hline Total & 116 & 100 & 116 & 100 & 116 & 100 & 116 & 100 \\
\hline
\end{tabular}

According to the data in table 15, no one disagrees better spoken English skill accompany with more chances to use English, the same case was that most of the subjects $(82.8 \%)$ associated speaking English well with better job opportunities. $77.6 \%$ of the subjects approve that Chinese people thought it important to speak English, which may drive them learn their major---English well.

The first three items are sorted as external motivations while the last item "I learn English with purpose of knowing the native speakers better" belongs to internal motivation which indicates learners' desire for learning lies in the interest in language itself. According to the data, only $11.2 \%$ are self-motivated, while $38.8 \%$ of them were not sure about this statement, which offers teachers an implication that measures should be taken to develop English majors' interests in language itself or they may quit easily as long as they come cross difficulties.

Beliefs about Classroom Teaching for English Learning

TABLE 16

MEAN SCORES OF CLASSROOM TEACHING FOR ENGLISH LEARNING

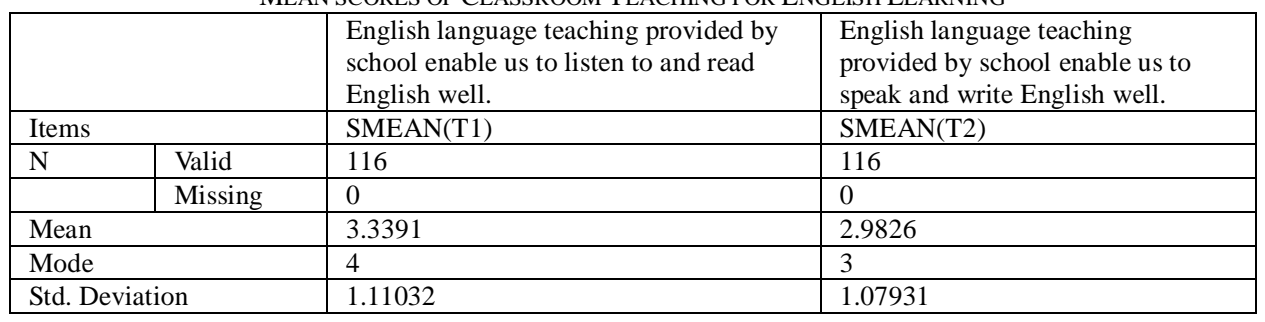

TABLE 17

FREQUENCY OF CLASSROOM TEACHING FOR ENGLISH LEARNING

\begin{tabular}{|l|l|l|l|l|l|l|l|}
\hline \multicolumn{2}{|c|}{} & 1 & 2 & 3 & 4 & 5 & Total \\
\hline \multirow{2}{*}{ T1 } & Fre. & 9 & 17 & 30 & 46 & 14 & 116 \\
\cline { 2 - 10 } & Per. & 7.8 & 14.7 & 25.9 & 39.7 & 12.1 & 100 \\
\hline \multirow{2}{*}{ T2 } & Fre. & 9 & 32 & 36 & 30 & 9 & 116 \\
\cline { 2 - 9 } & Per. & 7.8 & 27.6 & 31.2 & 25.9 & 7.8 & 100 \\
\hline
\end{tabular}

According the data in table 17 , more than half of the subjects $(51.8 \%)$ think that classroom teaching in university was enough for them to develop listening and reading skills, by comparison, only $33.9 \%$ think it is enough to develop speaking and writing skills, which urges school and teachers to create more and better chances for students to build their speaking and writing ability.

The Differences of Beliefs Before, after and Half a Year after Strategy Training

The Repeated Measure of One-way Analysis of Variance on Difficulty. 
TABLE 18

(难度: DIFFICULTY)

Within-Subjects Factors

Measure: MEASURE 1
\begin{tabular}{|l|l|}
\hline$d$ & $\begin{array}{l}\text { Dependent } \\
\text { Variable }\end{array}$ \\
\hline 1 & 难度 1 \\
2 & 难度 2 \\
3 & 难度 3 \\
\hline
\end{tabular}

Descriptive Statistics

\begin{tabular}{|l|c|r|r|}
\hline & Mean & Std. Deviation & \multicolumn{1}{c|}{ N } \\
\hline 难度1 & 3.5639 & .40707 & 116 \\
难度2 & 3.5299 & .39844 & 116 \\
难度3 & 3.4766 & .47957 & 116 \\
\hline
\end{tabular}

According to mean value in table 18, subjects' beliefs on the difficulty of language learning presents a decreasing trend. However, the difference above is substantial difference, whether it is statistically meaningful, related data are to be analyzed in table 20: Tests of Within-Subjects Effects.

Since repeated measure design violates the Independence Assumption of between subjects experiment design, therefore, the Sphericity Assumption should be confirmed. If the value of significance (sig.) in Mauchly's test $<0.05$, the Sphericity Assumption is violated, therefore, a remedial measure should be taken. According to statistical science, the sig. value of Greenhouse-Geisser, Huynh-Fedldt or Lower-bound, each of them can be chosen to regain the sig. value. By comparison, Lower-bound is considered as the most conservative method, although statistical significance is hard to achieve (Qin, 2003), therefore, the sig. value of Lower-bound in table "Tests of Within-subjects Effects" should be reported to evaluate the significance of factorial effect. Another case is that in Mauchly's test of sphericity, sig. value $>0.05$, which conforms to Sphericity Assumption, then, in table "Tests of Within-subjects Effects", the sig. value of Sphericity Assumed should be reported to evaluate the significance of factorial effect. In table "Tests of Withinsubjects Effects", if the sig. value $>0.05$, the significance cannot be regarded notable, if sig. value $<0.05$, the notable significance is achieved.

TABLE 19

MAUCHLY'S TEST OF SPHERICITY(B) MEASURE: MEASURE

\begin{tabular}{|l|l|l|l|l|l|l|l|}
\hline $\begin{array}{l}\text { WithinSubje } \\
\text { cts Effect }\end{array}$ & Mauchly'sW & $\begin{array}{l}\text { Approx. Chi- } \\
\text { Square }\end{array}$ & df & Sig. & $\begin{array}{l}\text { Epsilon (a) } \\
\text { Greenhouse-Geisser }\end{array}$ & Huynh-Feldt & Lower-bound \\
\hline & .902 & 11.766 & 2 & .003 & .911 & .925 & .500 \\
\hline D & &
\end{tabular}

Tests the null hypothesis that the error covariance matrix of the orthonormalized transformed dependent variables is proportional to an identity matrix.

a May be used to adjust the degrees of freedom for the averaged tests of significance. Corrected tests are displayed in the Tests of Within-Subjects Effects table.

b Design: Intercept

Within Subjects Design: d

TABLE 20

Tests of Within-Subjects Effects

Measure: MEASURE 1
\begin{tabular}{|ll|r|r|r|r|r|}
\hline Source & & $\begin{array}{c}\text { Type III Sum } \\
\text { of Squares }\end{array}$ & \multicolumn{1}{c|}{ df } & Mean Square & \multicolumn{1}{c|}{ F } & \multicolumn{1}{c|}{ Sig. } \\
\hline $\mathrm{d}$ & Sphericity Assumed & .449 & 2 & .225 & 1.321 & .269 \\
& Greenhouse-Geisser & .449 & 1.821 & .247 & 1.321 & .268 \\
& Huynh-Feldt & .449 & 1.849 & .243 & 1.321 & .268 \\
& Lower-bound & .449 & 1.000 & .449 & 1.321 & .253 \\
\hline Error(d) & Sphericity Assumed & 39.108 & 230 & .170 & & \\
& Greenhouse-Geisser & 39.108 & 209.460 & .187 & & \\
& Huynh-Feldt & 39.108 & 212.649 & .184 & & \\
& Lower-bound & 39.108 & 115.000 & .340 & & \\
\hline
\end{tabular}

In table 19, letter D stands for Difficulty. Sig. value reports 0.003 , which is lower than 0.05 , the sphericity assumption is violated, therefore, according the remedial measures mentioned before, the sig. value of Lower-bound should be checked, which is 0.253 , because $0.253>0.05$, the factorial effect is significant, but not notable. 
TABLE 21

Pairwise Comparisons

\begin{tabular}{|c|c|c|c|c|c|c|}
\hline \multirow[b]{2}{*}{ (l) $d$} & \multirow[b]{2}{*}{ (J) d } & \multirow{2}{*}{$\begin{array}{c}\text { Mean } \\
\text { Diff erence } \\
(I-J)\end{array}$} & \multirow[b]{2}{*}{ Std. Error } & \multirow[b]{2}{*}{ Sig. $^{a}$} & \multicolumn{2}{|c|}{$\begin{array}{l}\text { 95\% Confidence Interval for } \\
\text { Diff erence }\end{array}$} \\
\hline & & & & & Lower Bound & Upper Bound \\
\hline \multirow[t]{2}{*}{1} & 2 & .034 & .045 & 1.000 & -.075 & .143 \\
\hline & 3 & .087 & .059 & .431 & -.057 & .231 \\
\hline \multirow[t]{2}{*}{2} & 1 & -.034 & .045 & 1.000 & -.143 & .075 \\
\hline & 3 & .053 & .057 & 1.000 & -.085 & .192 \\
\hline \multirow[t]{2}{*}{3} & 1 & -.087 & .059 & .431 & -.231 & .057 \\
\hline & 2 & -.053 & .057 & 1.000 & -.192 & .085 \\
\hline
\end{tabular}

In table 21, the second vertical line displays the mean score differences among the three tests, the mean score of difficulty on language learning from delayed post-test decreased 0.053 compared to immediate post-test, and 0.087 compared to pre-test. This result shows the decreasing tendency of subjects' responses to beliefs on difficulty of language learning, but statistically speaking, the decreasing tendency mentioned is considered insignificant. However, the mean scores of each of the three tests with certain intervals keep decreasing, it is, from another perspective proves that subjects' beliefs on this item (difficulty of language learning) turned out a sustainable changing trend, although the change was tiny, it kept changing towards the same direction.

The Repeated Measure of One-way Analysis of Variance on Aptitude

TABLE 22

(能力: APTITUDE)

Within-Subjects Factors
\begin{tabular}{|l|l|}
\hline Measure: MEASURE 1 \\
\hline aptitude & $\begin{array}{l}\text { Dependent } \\
\text { Variable }\end{array}$ \\
\hline 1 & 能力 1 \\
2 & 能力 2 \\
3 & 能力 3 \\
\hline
\end{tabular}

\begin{tabular}{|l|c|r|r|}
\multicolumn{5}{c|}{ Descriptive Statistics } \\
\hline & Mean & Std. Deviation & \multicolumn{1}{c|}{$\mathrm{N}$} \\
\hline 能力1 & 3.3218 & .58760 & 116 \\
能力2 & 3.4234 & .59620 & 116 \\
能力3 & 3.4975 & .59408 & 116 \\
\hline
\end{tabular}

In table 22, 116 subjects' responses to beliefs about language learning aptitude represent an increasing tendency, which theoretically indicates that all the subjects become more and more affirmative to statements concerning human aptitude towards foreign language learning. To evaluate the changes are statistically significant or not, the sig. value in Mauchly's Test of Sphericity is to be checked.

TABLE 23

MAUCHLY'S TEST OF SPHERICITY(B) MEASURE: MEASURE_1

\begin{tabular}{|l|l|l|l|l|l|l|l|}
\hline $\begin{array}{l}\text { Within } \\
\text { Subjects Effect }\end{array}$ & Mauchly's W & $\begin{array}{l}\text { Approx. Chi- } \\
\text { Square }\end{array}$ & df & Sig. & Epsilon(a) & Huynh-Feldt & Lower-bound \\
\hline & & & & & Greenhouse-Geisser & .927 & .500 \\
\hline aptitude & .904 & 11.471 & 2 & .003 & .913 & .9 & \\
\hline
\end{tabular}

Tests the null hypothesis that the error covariance matrix of the orthonormalized transformed dependent variables is proportional to an identity matrix.

a May be used to adjust the degrees of freedom for the averaged tests of significance. Corrected tests are displayed in the Tests of Within-Subjects Effects table.

b Design: Intercept Within Subjects Design: aptitude 
TABLE 24

Tests of Within-Subjects Effects

Measure: MEASURE 1
\begin{tabular}{|ll|r|r|r|r|r|}
\hline Source & $\begin{array}{c}\text { Type III Sum } \\
\text { of Squares }\end{array}$ & \multicolumn{1}{c|}{ df } & Mean Square & F & \multicolumn{1}{c|}{ Sig. } \\
\hline aptitude & Sphericity Assumed & 1.804 & 2 & .902 & 5.369 & .005 \\
& Greenhouse-Geisser & 1.804 & 1.825 & .988 & 5.369 & .007 \\
& Huynh-Feldt & 1.804 & 1.853 & .973 & 5.369 & .006 \\
& Lower-bound & 1.804 & 1.000 & 1.804 & 5.369 & .022 \\
\hline Error(aptitude) & Sphericity Assumed & 38.631 & 230 & .168 & & \\
& Greenhouse-Geisser & 38.631 & 209.907 & .184 & & \\
& Huynh-Feldt & 38.631 & 213.115 & .181 & & \\
& Lower-bound & 38.631 & 115.000 & .336 & & \\
\hline
\end{tabular}

In table 23, sig. value $0.03<0.05$, following the rules mentioned before, the significance in Mauchly' test violated the Sphericity Assumption, adopting Lower-bound remedial measure, the sig. value of lower-bound in table 24 should be reported, which is 0.022 and is much lower than 0.05 , therefore reaches the statistical significance. This result indicates that subjects' beliefs on language learning aptitude differ significantly in different period of time, to know the details, information in table 25 is to be analyzed.

TABLE 25

Pairwise Comparisons

\begin{tabular}{|c|c|c|c|c|c|c|}
\hline \multirow[b]{2}{*}{ (I) aptitude } & \multirow[b]{2}{*}{ (J) aptitude } & \multirow{2}{*}{$\begin{array}{c}\text { Mean } \\
\text { Diff erence } \\
(\mathrm{I}-\mathrm{J})\end{array}$} & \multirow[b]{2}{*}{ Std. Error } & \multirow[b]{2}{*}{ Sig. ${ }^{a}$} & \multicolumn{2}{|c|}{$\begin{array}{c}\text { 95\% Confidence Interv al for } \\
\text { Diff erence }\end{array}$} \\
\hline & & & & & Lower Bound & Upper Bound \\
\hline \multirow[t]{2}{*}{1} & 2 & -.102 & .045 & .078 & -.211 & .008 \\
\hline & 3 & $-.176^{*}$ & .059 & .011 & -.320 & -.031 \\
\hline \multirow[t]{2}{*}{2} & 1 & .102 & .045 & .078 & -.008 & .211 \\
\hline & 3 & -.074 & .056 & .565 & -.210 & .062 \\
\hline \multirow[t]{2}{*}{3} & 1 & $.176^{*}$ & .059 & .011 & .031 & .320 \\
\hline & 2 & .074 & .056 & .565 & -.062 & .210 \\
\hline
\end{tabular}

The second vertical line displays the mean differences among each test, aptitude mean score from delayed pose-test (third test) increased 0.074 compared to immediate post-test (second test), and it increased 0.176 compared to pre-test (first test), which is regarded statistically significant according to *mark. Although it didn't achieve *mark as significant level, aptitude mean score from immediate delayed post-test still got 0.102 of increasing value compared to pre-test, which indicates a comparatively big change between cases before and after the language strategy training.

To sum up, the significant increase of the mean scores of language learning aptitude may partly attribute to the language strategy training, which arranged some contents related to mystery of human brain to guide students know more or less about the functions of each hemisphere of human brain, by discussing about language learning from biological standpoint, the students got a new understanding about language learning aptitude, which probably affect their responses to those items like "Learning English is easier for children than for adults" and "Some people are born with special talents for foreign language learning".

The Repeated Measure of One-way Analysis of Variance on Nature

TABLE 26

(性质: NATURE)

Within-Subjects Factors

\begin{tabular}{|l|l|} 
Measure: MEASURE_1 \\
\hline nature & $\begin{array}{l}\text { Dependent } \\
\text { Variable }\end{array}$ \\
\hline 1 & 性质 1 \\
2 & 性质 2 \\
3 & 性质 3 \\
\hline
\end{tabular}

\begin{tabular}{|c|c|c|c|}
\hline \multicolumn{4}{|c|}{ Descriptive Statistics } \\
\hline & Mean & Std. Deviation & $\mathrm{N}$ \\
\hline 性质1 & 3.5848 & .47625 & 116 \\
\hline 性质2 & 3.4530 & .55187 & 116 \\
\hline 性质3 & 3.4646 & .54148 & 116 \\
\hline
\end{tabular}

The mean value in 26 represents that after the strategy straining, responses to beliefs on nature of language learning decreased 0.1318, which means subjects' attitude towards some items about nature changed from positive to comparatively negative, to know the specific changes, mean scores of two items with biggest changes are listed below: 
TABLE 27

MEAN SCORES OF TWO ITEMS WITH BIGGEST CHANGES

\begin{tabular}{|l|l|l|}
\hline Mean scores & Pre-test & Immediate post-test \\
\hline Item 3 & 3.5000 & 3.4144 \\
\hline Item 5 & 3.7586 & 3.7182 \\
\hline
\end{tabular}

Items three states that "Vocabulary learning is the most important part in English learning", and item five is "Foreign language learning differs a lot from learning other subjects." The higher the mean score, the more you agree with the statement. When the subjects were tested after the training, mean scores of the two items showed comparative stronger decrease than other items.

The result may partly due to the language strategy training course which arranged courses concerning vocabulary learning, not only introducing specific strategies for handling new words which may facilitate students with words memorization and guessing, but also trying to release students' anxiety of new words learning. Besides, the whole training arrangement tried to balance the importance of different parts of English which is likely to guide students to try to avoid exerting efforts in only or two parts in English learning.

Language strategy training course involves some special examples for students to understand certain kind of issues, such as compare decomposing long words into smaller parts with case of division algorithm and factor resolution in math. Such kind of example may drive some of students to find common rules between English learning with other subjects. Therefore, they may gradually understand that English learning is not totally different from learning other subjects.

Whether the differences among three tests are statistically significant, table 28 is to be discussed.

TABLE 28

MAUCHLY'S TEST OF SPHERICITY(B)

MEASURE: MEASURE_1

\begin{tabular}{|c|c|c|c|c|c|c|c|}
\hline \multirow{2}{*}{$\begin{array}{l}\text { Within Subjects } \\
\text { Effect }\end{array}$} & \multirow{2}{*}{ Mauchly's W } & \multirow{2}{*}{$\begin{array}{l}\text { Approx. Chi- } \\
\text { Square }\end{array}$} & \multirow{2}{*}{ df } & \multirow{2}{*}{ Sig. } & \multicolumn{3}{|l|}{ Epsilon(a) } \\
\hline & & & & & Greenhouse-Geisser & Huynh-Feldt & Lower-bound \\
\hline nature & .994 & .740 & 2 & .691 & .994 & 1.000 & .500 \\
\hline
\end{tabular}

Tests the null hypothesis that the error covariance matrix of the orthonormalized transformed dependent variables is proportional to an identity matrix.

a May be used to adjust the degrees of freedom for the averaged tests of significance. Corrected tests are displayed in table 29.

b Design: Intercept.

Within Subjects Design: nature

TABLE 29

Tests of Within-Subjects Effects

Measure: MEASURE 1
\begin{tabular}{|ll|r|r|r|r|r|}
\hline \multirow{3}{*}{ Source } & & $\begin{array}{c}\text { Type III Sum } \\
\text { of Squares }\end{array}$ & \multicolumn{1}{c|}{ df } & Mean Square & \multicolumn{1}{c|}{ F } & \multicolumn{1}{c|}{ Sig. } \\
\hline nature & Sphericity Assumed & 1.235 & 2 & .617 & 3.410 & .035 \\
& Greenhouse-Geisser & 1.235 & 1.987 & .621 & 3.410 & .035 \\
& Huynh-Feldt & 1.235 & 2.000 & .617 & 3.410 & .035 \\
& Lower-bound & 1.235 & 1.000 & 1.235 & 3.410 & .067 \\
\hline Error(nature) & Sphericity Assumed & 41.650 & 230 & .181 & & \\
& Greenhouse-Geisser & 41.650 & 228.522 & .182 & & \\
& Huynh-Feldt & 41.650 & 230.000 & .181 & & \\
& Lower-bound & 41.650 & 115.000 & .362 & & \\
\hline
\end{tabular}

In table 28 , the sig. value shows 0.691 , which is higher than 0.05 , indicating that the value doesn't violate the Sphericity Assumption. Therefore, the item Sphericity Assumed should be checked to see whether sig. value reaches statistical significance. The sig. value of sphericity assumed in table 29 shows $0.035,0.035<0.05$, the statistical significance was achieved. The specific differences among each of the three tests are displayed in table 30. 
TABLE 30

Pairwise Comparisons

\begin{tabular}{|c|c|c|c|c|c|c|}
\hline \multirow[b]{2}{*}{ (I) nature } & \multirow[b]{2}{*}{ (J) nature } & \multirow{2}{*}{$\begin{array}{c}\text { Mean } \\
\text { Diff erence } \\
(I-J)\end{array}$} & \multirow[b]{2}{*}{ Std. Error } & \multirow[b]{2}{*}{ Sig. $^{\text {a }}$} & \multicolumn{2}{|c|}{$\begin{array}{c}\text { 95\% Confidence Interv al for } \\
\text { Diff erence }^{\text {a }}\end{array}$} \\
\hline & & & & & Lower Bound & Upper Bound \\
\hline \multirow[t]{2}{*}{1} & 2 & .132 & .058 & .075 & -.009 & .273 \\
\hline & 3 & .120 & .055 & .095 & -.014 & .254 \\
\hline \multirow[t]{2}{*}{2} & 1 & -.132 & .058 & .075 & -.273 & .009 \\
\hline & 3 & -.012 & .054 & 1.000 & -.143 & .120 \\
\hline \multirow[t]{2}{*}{3} & 1 & -.120 & .055 & .095 & -.254 & .014 \\
\hline & 2 & .012 & .054 & 1.000 & -.120 & .143 \\
\hline
\end{tabular}

Based on estimated marginal means

a. Adjustment for multiple comparisons: Bonf erroni.

Data in the second vertical line show that the mean score of beliefs on nature from immediate post-test decreased 0.132 compared to pre-test, and it increased 0.012 compared to delayed post-test, therefore, it remained the lowest value among the three tests. The typical decreased items which may cause the lowest value were shown in table 27 , and the reasons were given at the same time, which were obtained by tracing back to the language strategy training.

To sum up, subjects gave their responses to the nature of language learning, which include most of their preconceptions on what should be the most important task in English learning, how is English learning compared to learning other subjects? Since the language strategy training tried to balance the importance of each part of English learning by stressing each one's features, hopefully help students reorganize their ideas about the answers to the two kinds of questions mentioned above. Therefore, some of the subjects changed their ideas more or less, such as adjusted their opinions of the importance of each part of English learning, that's why mean score of the responses from immediate posttest turned out big changes. As for the delayed posttest, the mean score was a little higher than the second test but still lower than the first test, which indicate that the training influence remained with a certain degree even half a year after the training.

The Repeated Measure of One-way Analysis of Variance on Strategy

TABLE 31

(策略: STRATEGY)

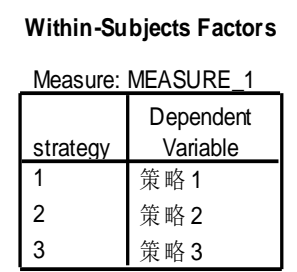

\begin{tabular}{|l|c|r|r|}
\multicolumn{4}{c|}{ Descriptive Statistics } \\
\hline & Mean & Std. Dev iation & \multicolumn{1}{c|}{ N } \\
\hline 策略1 & 3.4391 & .69197 & 116 \\
策略2 & 3.4178 & .34649 & 116 \\
策略3 & 3.3463 & .41268 & 116 \\
\hline
\end{tabular}

In table 31, language learning strategies represented a decreasing trend. To know clearly and what caused the results in above table, items with mean scores decreased apparently are presented in the table 32 .

TABLE 32.

MEAN SCORES DECREASED

\begin{tabular}{|l|l|l|}
\hline Mean scores & Pre-test & Immediate post-test \\
\hline Item 4 & 2.0086 & 1.7838 \\
\hline Item 7 & 2.7368 & 2.7328 \\
\hline Item 8 & 3.6207 & 2.0360 \\
\hline
\end{tabular}

The decrease of the three items probably caused the decreasing trend of mean scores of the three tests, which is expected to by the author, and the reason will be revealed as these three items are analyzed one by one.

Item four, seven and eight states respectively that "Never express yourself in English before you can say it correctly", "I feel shy when I speak with others", and "It will be difficult for beginners to say English correctly if they were allowed to make mistakes at the beginning stage of English learning." By analyzing the content of each item, it's easy to find that the more they are afraid of making mistakes in spoken English, the higher the mean scores will these three items be. However, the language strategy training arranged relative contents such as speaking courses, in which students were educated to seize chances to practice oral English, to be brave to open their mouth to express ideas and do not feel shy when speaking with others in English. Therefore, all the subjects were encouraged to take risks when dealing with problems in spoken English. The subjects who were affected by the training may change their ideas towards items mentioned above and if they understood and accepted ideas about communicative strategies in the training, the decease 
of mean scores from the test immediate after training can be explained.

TABLE 33

MAUCHLY'S TEST OF SPHERICITY(B)

MEASURE: MEASURE_1

\begin{tabular}{|l|l|l|l|l|l|l|l|}
\hline $\begin{array}{l}\text { Within Subjects } \\
\text { Effect }\end{array}$ & Mauchly's W & $\begin{array}{l}\text { Approx. Chi- } \\
\text { Square }\end{array}$ & df & Sig. & \multicolumn{2}{l|}{ Epsilon(a) } \\
\hline & & & & & Greenhouse-Geisser & Huynh-Feldt & Lower-bound \\
\hline strategy & .711 & 38.954 & 2 & .000 & .776 & .784 & .500 \\
\hline
\end{tabular}

Tests the null hypothesis that the error covariance matrix of the orthonormalized transformed dependent variables is proportional to an identity matrix.

a May be used to adjust the degrees of freedom for the averaged tests of significance. Corrected tests are displayed in table 34.

b Design: Intercept. Within Subjects Design: strategy

TABLE34

Tests of Within-Subjects Effects

\begin{tabular}{|c|c|c|c|c|c|c|}
\hline Source & & $\begin{array}{l}\text { Type III Sum } \\
\text { of Squares }\end{array}$ & $\mathrm{df}$ & Mean Square & $\mathrm{F}$ & Sig. \\
\hline \multirow[t]{4}{*}{ strategy } & Sphericity Assumed & .548 & 2 & .274 & 1.237 & .292 \\
\hline & Greenhouse-Geisser & .548 & 1.551 & .353 & 1.237 & .286 \\
\hline & Huynh-Feldt & .548 & 1.568 & .349 & 1.237 & .286 \\
\hline & Lower-bound & .548 & 1.000 & .548 & 1.237 & .268 \\
\hline \multirow[t]{4}{*}{ Error(strategy ) } & Sphericity Assumed & 50.932 & 230 & .221 & & \\
\hline & Greenhouse-Geisser & 50.932 & 178.372 & .286 & & \\
\hline & Huynh-Feldt & 50.932 & 180.356 & .282 & & \\
\hline & Lower-bound & 50.932 & 115.000 & .443 & & \\
\hline
\end{tabular}

Though the mean scores for the three tests represented a decreasing trend, the sig. value in table 32 proved it violated the Sphericity Assumption, then the sig. value of Lower-bound should be checked. According to table 34, the sig. value reported $0.268,0.268>0.05$, which implied insignificant differences among each test. Nevertheless, the changes of subjects' beliefs on learning and communicative strategies did exist.

\section{TABLE 35}

Pairwise Comparisons

\begin{tabular}{|c|c|c|c|c|c|c|}
\hline \multirow[b]{2}{*}{ (I) strategy } & \multirow[b]{2}{*}{ (J) strategy } & \multirow{2}{*}{$\begin{array}{c}\text { Mean } \\
\text { Dif } f \text { erence } \\
(\mathrm{I}-\mathrm{J})\end{array}$} & \multirow[b]{2}{*}{ Std. Error } & \multirow[b]{2}{*}{ Sig. ${ }^{a}$} & \multicolumn{2}{|c|}{$\begin{array}{l}\text { 95\% Confidence Interv al f or } \\
\text { Dif f erence }\end{array}$} \\
\hline & & & & & Lower Bound & Upper Bound \\
\hline \multirow[t]{2}{*}{1} & 2 & .021 & .067 & 1.000 & -.141 & .184 \\
\hline & 3 & .093 & .072 & .600 & -.082 & .268 \\
\hline \multirow[t]{2}{*}{2} & 1 & -.021 & .067 & 1.000 & -.184 & .141 \\
\hline & 3 & .071 & .042 & .286 & -.032 & .175 \\
\hline \multirow[t]{2}{*}{3} & 1 & -.093 & .072 & .600 & -.268 & .082 \\
\hline & 2 & -.071 & .042 & .286 & -.175 & .032 \\
\hline
\end{tabular}

Based on estimated marginal means

a. Adjustment for multiple comparisons: Bonferroni.

According to the data in the second vertical line, mean differences reported the following results: compared to pretest, mean score of immediate post-test decreased 0.021 and delayed post-test decreased 0.093. According to the analysis below table 32, the decrease of the mean score from immediate post-test can be explained, while the comparatively strong decrease of mean score from delayed post-test revealed the decreasing trend of each item.

To sum up, the mean scores of the three tests of learners' beliefs on learning and communication strategies turned out a decreasing trend, the mean score decrease of the second test due to the changes of subjects' ideas towards some items about oral English strategies, which owns to the contents and educating ideas in spoken English course in language strategy training. Since the second test was implemented right after the training course, the subjects' responses reflected directly that they were affected by the training. By contrast, the third tested was carried out half a year after the training, almost every item involved in this category decreased more or less, which indicates that learners need sustainable input to strengthen the positive influence on their beliefs. 


\section{The Repeated Measure of One-way Analysis of Variance on Motivation}

TABLE 36

(动机: MOTIVATION)

Within-Subjects Factors

\begin{tabular}{|l|l|}
\hline Measure: MEASURE_1 \\
$\mathrm{m}$ & $\begin{array}{c}\text { Dependent } \\
\text { Variable }\end{array}$ \\
\hline 1 & 动机 1 \\
2 & 动机 2 \\
3 & 动机 3 \\
\hline
\end{tabular}

\begin{tabular}{|c|c|c|c|}
\hline \multicolumn{4}{|c|}{ Descriptive Statistics } \\
\hline & Mean & Std. Deviation & $\mathrm{N}$ \\
\hline 动机1 & 3.8276 & .54215 & 116 \\
\hline 动机2 & 3.7973 & .61900 & 116 \\
\hline 动机3 & 3.8531 & 1.12666 & 116 \\
\hline
\end{tabular}

In table 36, mean score of the second test represented a tiny decrease compared to that of pre-test, while mean score of the third test turned out the highest value among the three tests. Whether this result is connected to the influence of the language strategy training, an analysis in details with each item of learners' beliefs on this category (motivation) is given below:

TABLE 37

MEAN SCORE COMPARISON OF ITEMS FROM BELIEFS ON MOTIVATION

\begin{tabular}{|l|l|l|l|}
\hline Mean score & Pre-test & Immediate post-test & Delayed post-test \\
\hline Item one & 4.4828 & 4.3423 & 4.1983 \\
\hline Item two & 4.3103 & 4.1982 & 4.5345 \\
\hline Item four & 2.4828 & 2.6126 & 2.8348 \\
\hline
\end{tabular}

As the data displayed in table 37, the decreasing trend of the second test mostly attribute to the decrease of item one and item two and since the responses of the second test were collected immediately after the language strategy training, this trend and the training are theoretically connected. The reason is that the language strategy training arranged a special part for learners' learning motivation, in which internal motivation and external motivation were introduced and explained. In the training course, all the subjects were induced to have stronger internal motivation rather than external motivation, because internal motivation represents learner' love and interest towards English learning and English culture, which may lead learners' to learn willingly and effectively without giving up easily; while external motivation involves various reasons for learning English most of which are benefits-driven, such as earning better job opportunities, more respects from people around.

The key point is that item one and item two are statements of external motivation for English learning which are: "If I could speak English well, I could have more chances to use it (item one)" and "If my English learning was excellent, I could get more chances for better job (item two)". Therefore, the mean score decreases of item one and two represent the weakening of subjects' external motivation, although the change was tiny according to the data.

Compared to item one and two, the content of item four is concerned with the internal motivation of English learning, which states: "I learn English is to understand native speakers better". According to table 37, mean scores of item four represent an increasing trend, although degree of increase turned out tiny, this result can partly be attributed to effectiveness of the training.

To know the mean score differences among the three tests are statistically significant or not, data of Mauchly' Test and Within-Subjects Effects will be checked.

TABLE 38

MAUCHLY'S TEST OF SPHERICITY(B) MEASURE: MEASURE 1

\begin{tabular}{|l|l|l|l|l|l|l|l|}
\hline $\begin{array}{l}\text { Within Subjects } \\
\text { Effect }\end{array}$ & Mauchly's W & $\begin{array}{l}\text { Approx. Chi- } \\
\text { Square }\end{array}$ & df & Sig. & \multicolumn{2}{l|}{ Epsilon(a) } \\
\hline & & & & & Greenhouse-Geisser & Huynh-Feldt & Lower-bound \\
\hline M & .708 & 39.356 & 2 & .000 & .774 & .783 & .500 \\
\hline
\end{tabular}

Tests the null hypothesis that the error covariance matrix of the orthonormalized transformed dependent variables is proportional to an identity matrix.

a May be used to adjust the degrees of freedom for the averaged tests of significance. Corrected tests are displayed in table 39.

b Design: Intercept. Within Subjects Design: m 
TABLE 39

\begin{tabular}{|c|c|c|c|c|c|c|}
\hline \multicolumn{7}{|c|}{ Tests of Within-Subjects Effects } \\
\hline \multicolumn{2}{|l|}{ Source } & $\begin{array}{l}\text { Type III Sum } \\
\text { of Squares }\end{array}$ & $\mathrm{df}$ & Mean Square & $\mathrm{F}$ & Sig. \\
\hline \multirow[t]{4}{*}{$\mathrm{m}$} & Sphericity Assumed & .181 & 2 & .091 & .178 & .837 \\
\hline & Greenhouse-Geisser & .181 & 1.548 & .117 & .178 & .781 \\
\hline & Huynh-Feldt & .181 & 1.565 & .116 & .178 & .783 \\
\hline & Lower-bound & .181 & 1.000 & .181 & .178 & .674 \\
\hline \multirow[t]{4}{*}{ Error(m) } & Sphericity Assumed & 116.954 & 230 & .508 & & \\
\hline & Greenhouse-Geisser & 116.954 & 178.027 & .657 & & \\
\hline & Huynh-Feldt & 116.954 & 179.998 & .650 & & \\
\hline & Lower-bound & 116.954 & 115.000 & 1.017 & & \\
\hline
\end{tabular}

The sig. value shown in table 38 is 0.000 , which is much lower than 0.05 , thus, it violates the Sphericity Assumption, then the sig. value of Lower-bound should be checked. According to the data in table 39, the sig. value reported as 0.674 , which is higher than 0.05 . Therefore, the changes of the mean scores among the three tests on learners' beliefs of learning motivation did exist but were not statistically significant.

However, items of beliefs on motivation involves both internal and external motivation, and the mean scores of the internal motivation (item four) has been proved an increase trend according to data in table 37 , to know whether it achieved statistical significance, specific information for item four is given below:

TABLE 40

COMPARISON INFORMATION OF ITEM FOUR OF MOTIVATION MAUCHLY'S TEST OF SPHERICITY(B)

MEASURE: MEASURE_1

\begin{tabular}{|l|l|l|l|l|l|l|l|}
\hline $\begin{array}{l}\text { Within } \\
\text { Subjects Effect }\end{array}$ & Mauchly's W & $\begin{array}{l}\text { Approx. Chi- } \\
\text { Square }\end{array}$ & df & Sig. & \multicolumn{2}{|l|}{ Epsilon(a) } \\
\hline & & & & & Greenhouse-Geisser & Huynh-Feldt & Lower-bound \\
\hline $\mathrm{m} 4$ & .998 & .181 & 2 & .914 & .998 & 1.000 & .500 \\
\hline
\end{tabular}

Tests the null hypothesis that the error covariance matrix of the orthonormalized transformed dependent variables is proportional to an identity matrix.

a May be used to adjust the degrees of freedom for the averaged tests of significance. Corrected tests are displayed in the Tests of Within-Subjects Effects table.

b Design: Intercept. Within Subjects Design: m4

TABLE 41

TESTS OF WITHIN-SUBJECTS EFFECTS

\begin{tabular}{|c|c|c|c|c|c|c|}
\hline Source & & $\begin{array}{l}\text { Ty pe III Sum } \\
\text { of Squares }\end{array}$ & df & Mean Square & $\mathrm{F}$ & Sig. \\
\hline \multirow[t]{4}{*}{$\mathrm{m} 4$} & Sphericity Assumed & 7.352 & 2 & 3.676 & 5.406 & .005 \\
\hline & Greenhouse-Geisser & 7.352 & 1.997 & 3.682 & 5.406 & .005 \\
\hline & Huynh-Feldt & 7.352 & 2.000 & 3.676 & 5.406 & .005 \\
\hline & Lower-bound & 7.352 & 1.000 & 7.352 & 5.406 & .022 \\
\hline \multirow[t]{4}{*}{ Error(m4) } & Sphericity Assumed & 156.389 & 230 & .680 & & \\
\hline & Greenhouse-Geisser & 156.389 & 229.636 & .681 & & \\
\hline & Huynh-Feldt & 156.389 & 230.000 & .680 & & \\
\hline & Lower-bound & 156.389 & 115.000 & 1.360 & & \\
\hline
\end{tabular}

TABLE 42

PAIRWISE COMPARISONS

\begin{tabular}{|c|c|c|c|c|c|c|}
\hline \multirow[b]{2}{*}{ (I) $\mathrm{m} 4$} & \multirow[b]{2}{*}{ (J) $\mathrm{m} 4$} & \multirow{2}{*}{$\begin{array}{c}\text { Mean } \\
\text { Diff erence } \\
(I-J)\end{array}$} & \multirow[b]{2}{*}{ Std. Error } & \multirow[b]{2}{*}{ Sig. $^{a}$} & \multicolumn{2}{|c|}{$\begin{array}{c}\text { 95\% Confidence Interval for } \\
\text { Diff erence }\end{array}$} \\
\hline & & & & & Lower Bound & Upper Bound \\
\hline \multirow[t]{2}{*}{1} & 2 & -.130 & .106 & .671 & -.388 & .128 \\
\hline & 3 & $-.352^{*}$ & .110 & .005 & -.618 & -.086 \\
\hline \multirow[t]{2}{*}{2} & 1 & .130 & .106 & .671 & -.128 & .388 \\
\hline & 3 & -.222 & .109 & .132 & -.487 & .043 \\
\hline \multirow[t]{2}{*}{3} & 1 & $.352^{\star}$ & .110 & .005 & .086 & .618 \\
\hline & 2 & .222 & .109 & .132 & -.043 & .487 \\
\hline
\end{tabular}

Based on estimated marginal means

*. The mean difference is signif icant at the .05 level.

a. Adjustment for multiple comparisons: Bonf erroni. 
According to data displayed in table 40, the sig. value of Mauchly' test of sphericity assumption (0.914) was much high than 0.05 , which conformed to sphericity assumption, and the sig. value of sphericity assumed turned out to be $0.005,0.005<0.05$, this result showed that the increase of mean scores on item four (internal motivation) reached statistical significance, the *mark from Mean Difference in Parise Comparison also proved this significance.

To sum up, the mean score differences of subjects' responses to beliefs on motivation didn't reach statistical significance, however, item for internal motivation represented an obvious increasing trend, and according to statistical data, it was proved that the increase was statistically significant. The increase mostly due to the effectiveness of language strategy training, in which the contents about learning motivation were arranged and subjects were educated to hold stronger internal motivation to facilitate English learning. Besides, the truth that the mean scores of this item kept increasing with significant degree may imply a sustainable effectiveness of the training on learners' beliefs towards internal motivation.

The Repeated Measure of One-way Analysis of Variance on Teaching

TABLE 43

(教学:TEACHING)

Within-Subjects Factors
\begin{tabular}{|l|l|}
\hline Measure: MEASURE 1 \\
\hline teaching & $\begin{array}{c}\text { Dependent } \\
\text { Variable }\end{array}$ \\
\hline 1 & 教学 1 \\
2 & 教学 2 \\
3 & 教学 3 \\
\hline
\end{tabular}

Descriptive Statistics
\begin{tabular}{|l|r|r|r|}
\hline & \multicolumn{1}{|c|}{ Mean } & Std. Deviation & \multicolumn{1}{c|}{ N } \\
\hline 教学1 & 3.1609 & 1.00119 & 116 \\
教学2 & 3.0935 & .91159 & 116 \\
教学3 & 3.0474 & 1.06113 & 116 \\
\hline
\end{tabular}

TABLE 44

MAUCHLY'S TEST OF SPHERICITY(B)

MEASURE: MEASURE_1

\begin{tabular}{|l|l|l|l|l|l|l|l|}
\hline $\begin{array}{l}\text { Within Subjects } \\
\text { Effect }\end{array}$ & Mauchly's W & $\begin{array}{l}\text { Approx. Chi- } \\
\text { Square }\end{array}$ & df & Sig. & \multicolumn{2}{l|}{ Epsilon(a) } \\
\hline & & & & & Greenhouse-Geisser & Huynh-Feldt & Lower-bound \\
\hline teaching & .972 & 3.222 & 2 & .200 & .973 & .989 & .500 \\
\hline
\end{tabular}

Tests the null hypothesis that the error covariance matrix of the orthonormalized transformed dependent variables is proportional to an identity matrix.

a May be used to adjust the degrees of freedom for the averaged tests of significance. Corrected tests are displayed in the Tests of Within-Subjects Effects table.

b Design: Intercept. Within Subjects Design: teaching

TABLE 45

TESTS OF WITHIN-SUBJECTS EFFECTS

\begin{tabular}{|c|c|c|c|c|c|c|}
\hline Source & & $\begin{array}{l}\text { Type III Sum } \\
\text { of Squares }\end{array}$ & df & Mean Square & $F$ & Sig. \\
\hline \multirow[t]{4}{*}{ teaching } & Sphericity Assumed & .755 & 2 & .378 & .518 & .596 \\
\hline & Greenhouse-Geisser & .755 & 1.946 & .388 & .518 & .591 \\
\hline & Huynh-Feldt & .755 & 1.979 & .382 & .518 & .594 \\
\hline & Lower-bound & .755 & 1.000 & .755 & .518 & .473 \\
\hline \multirow[t]{4}{*}{ Error(teaching) } & Sphericity Assumed & 167.648 & 230 & .729 & & \\
\hline & Greenhouse-Geisser & 167.648 & 223.765 & .749 & & \\
\hline & Huy nh-Feldt & 167.648 & 227.561 & .737 & & \\
\hline & Lower-bound & 167.648 & 115.000 & 1.458 & & \\
\hline
\end{tabular}

The mean scores in table 43 represented a decreasing trend which indicated that subjects felt more and more unsatisfied with English learning situations at school for their listening, reading, speaking and writing. The sig. value $(0.2>0.05)$ followed the Spericity Assumption, then the sig. value of sphericity assumed was checked and turned out to be $0.596>0.05$, therefore, the changes of mean scores among the three tests on subjects' beliefs of classroom teaching didn't reach statistical significance.

Taking the learning context--- engineering university in southwest Chinese into consideration, studying in engineering university, English majors may feel inadequate humanistic learning resources or atmosphere, this reason makes the result understandable.

\section{Results and Discussion on the Interview}

How does the training affect learners' beliefs corresponding with what students report?

1. What is your biggest problem in English language learning? Why?

2. Are you getting used to make plan for language learning? What are your short-term and long-term goals?

3. What are the qualities are you looking for a good language learner?

4. How does the language strategy training course influence your language learning? What are your suggestions for 
the training?

For the first question, every subject has different problems in English learning. However, each of the nine subjects mentioned speaking as their biggest problem in English learning. Only two of them are afraid to speak, but the rest of them feel the lack of vocabulary when speaking and feel unconfident in their pronunciation. All of them expected an excellent pronunciation.

For the second question, only two of the nine subjects persisted to make learning plans, and they happened to be the students with highest scores (scores for college admission) among the nine, and the rest of them made plans occasionally or rarely did it. As for short-term goals, almost every subject was struggling to pass the final exam. When it comes to long-term goals, it varied from person to person, generally speaking, it fell into two categories: for in-depth studying in English and for good jobs. Two subjects with the highest scores replied that for long-term goal, they expected to become English master, so they would learn more about English culture and they have such confidence; three of the subjects said that they wanted to become translators in the future, and the rest of the nine mentioned they wanted to find a suitable job in which they could use English.

For the third question, the nine subjects mentioned two aspects: motivation and personality. Subject with the highest score stressed internal motivation, she thought a good language learner should learn out of interest, only with interest and love for English learning, can the learner persist and learn by all means. Other subjects looked for these qualities in a good language learner: strong determination, self-regulation, out-going personality, willingness for communicating with others. They emphasized self-regulation most.

The answers for the last question cover several aspects:

First, for the influence of the training:

one of the nine subjects thought lecture of reading was helpful which boosted her interest to read more and she began to learn to read with depth as well as width; two of the nine subjects felt the lecture of speaking was helpful, because they were encouraged to speak bravely and they thought it quite important to speak first and then practice more to speak correctly; three of the nine thought lecture of vocabulary was helpful because they learnt many specific strategies to handle new words, they felt they really got something in that lecture; and the rest of the nine subjects thought the first lecture---Know Yourself was impressive and helpful, because they learn to know what kind of learners they are. In addition, all the subjects showed approval to the teaching form---Team teaching.

Second, for the suggestions for the training:

Two of the nine subjects expected more contents concerning foreign culture, and the rest of the subjects asked for more specific language learning strategies. All of them suggested more activities to be involved in the training class for them to participate, compared to being listeners; they preferred to learn by doing.

\section{IMPLICATION}

TCLTSP strategy training is proved to be beneficial to English learners in correcting their beliefs according to positive changes from the study. However, more attention should be paid to learners' ideas, more communications and ideas exchanges are needed before and during the preparation of training courses. Though the training is language learning strategies based, since the subjects are English majors, who need comprehensive skills and knowledge for being distinguished from non-English majors, more contents concerning spoken English and foreign cultures should be taken into consideration. Besides, according to the interview, most students stressed the quality of self-management, which is of great value for taking conscious control of learning process. Therefore, contents related to metacognition may need to be increased in future strategy training.

\section{REFERENCES}

[1] Gao, L. (2017). A New Model and Its Practice in Language Learning Strategy Training. Journal of Language Teaching and Research, 8, 383-390.

[2] Horwitz, E. K. (1987). Surveying student beliefs about language learning. In: Wenden, A. L., Rubin, J. (Eds.), Learner Strategy in Language Learning. Englewood Cliffs, NJ: Prentice-Hall, 119-129.

[3] Horwitz, E.K. (1988). The beliefs about language learning of beginning university foreign language students. The Modern Language Journal, 72 (3), 283-294.

[4] Jiao, Y. Y. (2006). A survey study of beliefs about English language learning held by third-year English majors in SWPU. M.A. dissertation, Southwest Petroleum University.

[5] Oxford, R. L. (1990). Language Learning Strategies: What Every Teacher Should Know. Boston: Heinle \&Heinle.

[6] Wen, Q.F. (1995). Differences in Learning Methods between Successful and unsuccessful English Learners. Foreign Language Teaching and Research, 3, 61-66.

[7] Wen, Q.F. (2001). The Changing Rules and Characteristics of English Learning Motivation, Beliefs and Strategy. Foreign Language Teaching and Research, 2, 105-110.

[8] Yang, N.D. (1999). The relationship between EFL learners' beliefs and learning strategy use. System, 27, 515-535. 
Na Yang was born in Zitong County, Sichuan Province, China in 1984. She received her master's degree in linguistics from Southwest Petroleum University, China in 2010.

She is currently a lecturer in the School of Foreign Languages, Southwest Petroleum University, Chengdu, China. Her research interests include second language acquisition and psycholinguistics.

Li Gao was born in Chengdu, China in 1982. She received her master's degree in linguistics from Southwest Petroleum University, China in 2010.

She is currently an associate professor in the School of Foreign Languages, Southwest Petroleum University, Chengdu, China. Her research interests include psycholinguistics, second language acquisition and corpus linguistics.

Jie Zeng was born in Nanchong, China in 1963. She received her Bachelor's degree in Literature from Southwest University, China.

She is currently a professor in the School of Foreign Languages, Southwest Petroleum University, Chengdu, China. Her research interests include psycholinguistics and second language acquisition. 